\title{
HEALTH PRODUCTION IN ADVERSE CONTEXTS: A STUDY OF THE PATHS OF COAS.
}

Author: Priscila Arruda da Silva. Nurse. PhD student in Nursing of the Program of Postgraduate in Nursing at the Rio Grande Federal University - FURG, RS - Brazil. E-mail: patitaarruda@yahoo.com.br

Advisor: Mara Regina Santos da Silva. Nurse. Professor of Postgraduate program in Nursing at the Rio Grande Federal University - FURG. PhD in Nursing. E-mail: marare@brturbo.com.br

Bibliography Reference: SILVA, PA. Health production in adverse contexts: a study of the trajectories of children of alcoholics. 2011. Dissertation (master's degree in nursing) - Postgraduate Program in Nursing, at the Rio Grande Federal University - FURG, Rio Grande.

Introduction: Parents' alcoholism is recognized as one of the many conditions that contribute significantly so that a family is constituted in an adverse context for the development of the children. It is associated to the high rates of reproduction over generations, though this is not a universal occurrence, given that many families are able to mobilize support and protection existing in the surroundings and prevent or repair the damage that alcoholism causes in family life.

Objective: This study aimed as a whole at understanding the characteristics and processes experienced by children of alcoholics, in different levels of their life context, which enable them to manage in a positive manner the negative experiences generated from the addiction of their parents. As specific objectives: (1) identify and analyze the personal characteristics that, according to the viewpoint of children of alcoholics, helped them in coping with negative experiences they have experienced as a result of parental addiction throughout childhood and adolescence; (2) analyze the significant family interactions that have contributed to avoid and/or lessen the negative consequences of parental alcoholism in the adult life of the children.

Methodology: It is about a qualitative study that used as a theoretical reference the concept of resilience, which was attended by five families living in a municipality in the extreme south of Brazil. Data collection occurred between November/2010 and January/2011, through semi-structured interviews and genogram, conducted with the children of alcoholic parents. For the organization and analysis of data matrices were built based on the concept of resilience and the objectives of this study. Ethical procedures were followed according to the recommendations of the Ordinance 2048/2009 of the Research with humans. The project was approved by the Ethics Committee for Research in Healthcare at the Rio Grande Federal University under the number 23116.005254/02010-01.

Results: The results show that in addition to personal characteristics already identified in other studies, such as self-esteem, confidence, self-control, affectionate and flexible nature, the abilities of the child are also highlighted: to establish distance from the critical experiences; to perceive himself and live differently from their parents; see themselves in the future. Likewise, we highlight the development of a nucleus of strengthening and the interactions of protection and care, established among family members.

Conclusion: The results of this study reaffirm that, despite high rates of reproduction of alcoholism through the generations, the people who grew up living 
with this problem can build a positive life trajectory, provided that the relationships and characteristics that protect them can be developed.

Descriptors: Family. Alcoholism. Resilience. Mental health. Nursing.

\section{Main Bibliography:}

1. Burke S; Schimied V; Montrose M. Literature Review: Parental Alcohol Misuse and the impact on children. Department of Community Services, NSW, 2006.

2. Christoffersen MN; Soothill K. The long-term consequences of parental alcohol abuse: a cohort study of children in Denmark. Journal of Substance Abuse Treatment. 2003; 25(2): 107-116

3. Bronfenbrenner U; Morris P A. The ecology of developmental process. In: Lerner RM. (ed.). Handbook of child psychology: Theoretical models of human development, 1998. 5. ed. 993-1028.

4. Cyrulnik B. Les vilans petit canards. Paris: Odile Jacob;2001.

5. Rutter M. Implications of resilience concepts for scientific understanding. Annals of the New York Academy of Sciences.2006; 1094 (1):1-12.

6. Luthar S, Sawyer JA, Brown PJ. Conceptual Issues in Studies of Resilience: Past, Present, and Future Research. Annals of the New York Academy of Sciences.2006; 1094 (1): 105-115.

7. Silva MRS, Lacharité C, Silva PA, Lunardi VL, Lunardi filho WD. Processos que sustentam a resiliência familiar: um estudo de caso. Texto e Contexto Enferm. 2009; 18 (1): 92-9.

Mailing Address: Mara Regina Santos da Silva, Rua Antônio Carlos de Andrade, 750. Neighborhood: Cassino. CEP: 96208-050 - Rio Grande - RS. E-mail: marare@brturbo.com.br.

Exam Date: February $24^{\text {th }}$, 2011. Institution: Rio Grande Federal University-FURG. Examiners: Francisca Lucélia Ribeiro de Farias; Marta Regina Cezar-Vaz; Marlene Teda Pelzer. 